\title{
TRADE, FOREIGN DIRECT INVESTMENT OR ACQUISITION: OPTIMAL ENTRY MODES FOR MULTINATIONALS
}

\author{
THEO EICHER \\ JONG WOO KANG \\ CESIFO WORKING PAPER NO. 1174 \\ CAtegory 7: Trade Policy \\ APRIL 2004
}
An electronic version of the paper may be downloaded
- from the SSRN website: www.SSRN.com
- from the CESifo website: www.CESifo.de




\title{
TRADE, FOREIGN DIRECT INVESTMENT OR ACQUISITION: OPTIMAL ENTRY MODES FOR MULTINATIONALS
}

\begin{abstract}
We examine multinationals' optimal entry modes into foreign markets as a function of market size, FDI fixed costs, tariffs and transport costs. Our results highlight why large countries are more likely to attract acquisition investment, while intermediate-sized countries may be served predominantly through trade, even in the presence of high tariffs. Small countries are most likely to experience either FDI or no entry. We also show how these results vary with the competition intensity in the host country.

FDI fixed costs, tariffs and transport costs are crucial not only in determining whether to engage in FDI or trade, but they are also shown to influence the acquisition choice as trade and FDI threats influence the acquisition price. Finally we explore the welfare implications of tariff reductions for both the local firm and the multinational and investigate political motives to impose endogenous tariffs that influence not only the welfare of a local firm, but also the entry mode of the multinational.
\end{abstract}

JEL classification: $\mathrm{O} 0$.

Theo Eicher

University of Washington

Department of Economics

301 Savery Hall

Box 353330

Seattle, Washington, 98195-3330

U.S.A.

TE@u.washington.edu
Jong Woo Kang

National Economic Advisory Council

5th Floor, Korea Productivity Center Building

122-1 Juksun-dong, Chongro-ku

Seoul 110-752

Korea

Jwkang67@hanmail.net

We thank Thomas Mueller and two referees for valuable comments. Theo Eicher thanks CESifo for its hospitality. Eicher was supported by a DFG Mercator Grant and by the UW Royalty Research fund. 


\section{Introduction}

Eastern Europe provided a natural experiment to examine multinationals' (MNCs') entry decisions, as transition economies were largely closed to trade, investment and acquisition until the late 1980s. In the following decade, the subsequent pattern of MNCs' entry proved to be much more diverse than initially predicted. ${ }^{1}$ As MNCs' FDI/acquisition and export patterns differed so remarkably across transition economies, the analysis of the determinants of MNCs' entry modes received renewed interest (e.g., UN 1999; World Bank 2002). ${ }^{2}$ In this paper we seek to examine how market structure, market size, tariffs and transport costs influence the entry behavior of MNCs.

The previous theoretical literature on MNC entry modes is separated into three important areas. One strand examines FDI/multiplant-production (e.g., Dunning 1981, Ethier 1986, Markusen 1984, Helpman 1984, 1985). A second set of models explores strategic aspects of the FDI/trade decision, such as tariff jumping FDI (e.g., Magee 1977, Horstmann and Markusen 1992, Motta 1992, Buckley and Casson 1998), and a third category analyzes the choice between FDI and acquisition/joint ventures (e.g., Hennart and Park, 1993, Smarzynska, 2000, and Mueller, 2001) in the absence of tariffs and transport costs. We combine key aspects of each of the previous approaches to construct one integrated theoretical framework that allows for all three entry modes. This allows

\footnotetext{
${ }^{1}$ The incentives for entry based on new and expanding markets, skilled labor, and (to a lesser degree) low labor costs as well as the surprising diversity of investments and entry modes across countries is documented in many surveys, e.g., Collins and Rodrik (1991), EBRD (1994), Meyer (2001), and Lankes and Venables (1996).

${ }^{2}$ Empirical models of entry modes include Lu (2002), Meyer (2001) and Davis, Desai and Francis (2000) who investigate institutional aspects, Henisz (2000), who examines political hazards, Shenkar (2001) and Brouthers and Brouthers (2001) who focus on cultural distance, Meyer and Estrin (2001) and Siripaisalpipat and Hoshino (2000) who examine the importance of resource transfers and MNC's specific advantages, and Brouthers, Brouthers and Werner (1999), who investigate the importance of Dunning's (1981) OLI variables.
} 
us to examine the determinants of MNCs' entry decisions as a function of tariffs/transport costs, FDI fixed costs, market size and market structure.

Our results indicate that entry decisions can be conveniently grouped by the degree of competition (or product differentiation). High degrees of competition reduce the likelihood that MNCs coexist with local firms, as the low cost producer is poised to remain the monopoly supplier. Sufficiently weak competition allows for coexistence and rich strategic entry mode interaction between local firms and MNCs. This result finds empirical support in World Bank (1999) where differential trade and FDI experiences of transition economies are explained by the degree of monopoly protection and tariff protection during the early stages of privatization, and by differential degrees of willingness of countries to bow to EU and WTO pressures to increase competition and lower tariffs. Collins and Rodrik (1991) report survey results that indicate the importance of market structure as a perceived attraction for investment in Eastern Europe.

If an MNC enters, we show that the entry mode depends on investment costs, tariff/transportation costs, competition and local market size. Not surprisingly, trade entry declines in tariffs and transport costs, giving rise to FDI, acquisition, or no-entry depending on fixed costs and market size. The fact that not only tariffs, but also transport costs matter is a key finding of Collins and Rodrik (1991), who show that proximity to the EU is an important aspect in the decision to export or invest.

FDI, in contrast, is shown to decline in fixed costs, inducing trade, acquisition, or noentry, depending on market size and degree of competition. Acquisitions increase in monopoly profits and market size, especially if FDI and Trade can be used as entry threats. These results confirm the findings summarized in Markusen's (1995) survey of 
MNCs' entry decisions that FDI increases relative to trade when tariffs and transport costs are high. Below we extend this result and highlight its dependence on the degree of competition and fixed costs.

Trade entry is shown to be most likely in countries that are located close to the MNC's production location, impose low tariffs, or represent intermediate sized markets. In large markets, it is optimal for the MNC to use trade or FDI threats to acquire the local firm and become a monopoly supplier. In small markets, with little demand and low goods prices, acquisitions and trade become unlikely in the face of tariffs because an MNC is unable to recover the acquisition price or marginal production costs. In such small markets FDI is only possible if fixed costs are extremely low or competition (and hence the MNC's cost advantage) is significant. Lankes and Venables (1996) confirm that the host country's market size is a driving force behind the FDI in Eastern Europe.

Our results regarding the relationship between investment/trade cost and the MNC's incentive for FDI/trade entry are akin to Horstmann and Markusen's (1992) who consider the emergence of an MNC in identical countries within homogeneous goods. The added dimension here is that we further differentiate the Horstmann and Markusen results as a function of market size, competition and investment/trade costs. Furthermore we offer the MNC an additional entry mode by allowing for acquisition.

Buckley and Casson (1998) extend Motta's (1992) export/FDI analysis to include licensing, to find that tariffs and transport costs encourage FDI, while Hill, et al (1990) find that the existence of large monopoly rents favors acquisition over FDI. These results are akin to ours, for given levels of investment/trade costs and market sizes. We then 
allow investment/trade costs and market size to vary and observe the resulting dynamic changes in entry decisions.

Hennart and Park (1993) examine the choice between FDI and acquisition, predicting that higher rates of growth in the target market increase investors' incentives to enter through acquisition. This confirms Mueller's (2001) results and our case of the prohibitive tariffs. If tariffs are low, however, relatively large markets may well be served by trade or FDI, depending on the relative size of fixed costs and the degree of competition.

We then proceed to examine the trade and welfare implications associated with different entry modes and tariff levels. The analysis reveals the surprising result that the local firm may not always be harmed by lowered tariffs. Clearly, an exporting MNC is better off as tariffs are lowered if it chooses trade over FDI. This welfare gain translates into the usual welfare loss for the import competing local firm. If lowered tariffs and trade creation induce MNCs to switch to trade rather than choose FDI, prices in the local market may rise. Local firms may indeed benefit from such a tariff reduction, if the price gains outweigh market share losses.

Lastly we investigate how political pressures may give rise to endogenous tariffs that influence MNCs' entry modes. We employ Hillman's political support approach where policy makers weigh political support from local firms and consumers. We show that the endogenous tariff renders governments more likely to impose tariffs in sectors that feature relatively inefficient (efficient) local firms (MNCs). Tariffs also increase in the competition intensity of an industry, except in very large markets in which governments put strong emphasis on firm profits. The model provides theoretical support that larger 
markets should experience freer trade, hence rapidly expanding markets also provide less of an incentive for governments to impose tariffs.

It is important to add that the data on MNC expansion strategies reflect more strategies than any model can hope to capture. Hanson, Mataloni and Slaughter (2001) provide empirical evidence that tariff induced FDI, acquisition, as well as exports are important. Their work highlights the importance of re-exporting (see also Feenstra and Hanson 2001), outsourcing (Feenstra and Hanson 1996), distribution oriented FDI, and the simultaneity of FDI, acquisition and export strategies. Re-exporting is a serious issue for all empirical work on MNC location. The re-export option could occur naturally in the model below, if we extended the model to three countries and allowed the MNC's FDI to lower production costs. From the intuition of the model we can conjecture that MNC's would relocate to lower production cost and geographically speaking the relocation would take place near large markets that have high fixed costs and low tariffs. The formal extension is not considered below because of the complexity of the game in the case of a three-country model. Outsourcing FDI has not been considered because the model lacks any vertical integration structure. Both extensions are left for future research.

\section{The Model}

Our formal structure below extends Mueller (2001) to allow for international trade and transport costs, which allows us to examine the dynamics of a three stage entry game between a local firm and its MNC rival. We assume that both firms have Bertrand conjectures about the rival's actions. At the first stage, the MNC has four options. It can 
submit a take-it-or-leave-it offer to acquire the local firm, implement FDI, export the good, or refrain from entering the market. ${ }^{3}$ If the MNC acquires the local firm, it becomes the monopoly producer. At the second stage, the local firm accepts or rejects the acquisition offer. If the offer is rejected, the MNC chooses between FDI, trade, or no entry in a third stage. To derive the MNC's optimal entry mode, we search for sub-game perfect equilibria through backward induction.

The local firm produces with constant marginal cost, $c_{L}$, while the MNC possesses an ownership advantage represented by $c_{M}<c_{L}$. If the MNC engages in FDI, it incurs fixed costs, $k$, and marginal cost $c_{M}{ }^{4}$ In contrast, MNC exports are subject to tariffs and transport costs, $\tau$ and $\sigma$, respectively, which raise the MNC's marginal production cost to $c_{T}=c_{M}+\tau+\sigma$. Depending on the level of tariffs/transport costs, $c_{T}$ may or may not exceed $c_{L}$.

For now we assume that the MNC continues to employ the existing, local technology with production $\operatorname{cost} c_{L}$ if the local firm is acquired. Hence, acquisition never leads to a cost advantage, only to monopoly status. The acquisition costs equal the local firm's expected profits, which in turn depend crucially on the MNC's mode of entry. ${ }^{5}$ Following Hotelling's Linear City model, consumers are uniformly distributed along the $[0,1]$ interval, and goods are differentiated in the sense that consumers pay the price plus

\footnotetext{
3 For the purposes of this paper we separate MNCs' foreign investment into "acquisition" and FDI. Acquisition is assumed to be the take over of a foreign firm and FDI is taken as synonym for a new investment (the literature also refers to such FDI also as "greenfield investment"). Portfolio investment is not considered, nor is FDI for re-export purposes.

${ }^{4}$ Examples of such fixed costs could be production related infrastructure or institutional costs (such as a lack of transparency in laws, regulations and systems). The cost $k$ could also be set up cost for the investment itself.

${ }^{5}$ Other possible assumptions, such as lower marginal cost if the local firm is acquired, are certainly possible but not considered here to limit the complexity of the model.
} 
a travel cost, $t$, to the firm location. ${ }^{6}$ As travel costs increase, competition between the two firms falls. Agents consume zero or one unit of the good to attain a gross consumers' surplus, $s$. Broadly speaking, $s$ is a measure of the size of the local market. Let $p_{L}$ and $p_{F}$ denote the prices charged by the local firm and the $\mathrm{MNC}$, respectively, where the subscripts $F=M, T$ represent $M$ in the case of FDI, and $T$ in case of export.

The gross price to a consumer who shops at the local firm with coordinate $x$ is $p_{L}+t x$, while the gross price at the MNC is $p_{F}+t(1-x)$. Hence, in the case of FDI or trade, the net utility of a consumer located at $x$ is

$$
U= \begin{cases}s-p_{L}-t x & \text { for local goods } \\ s-p_{F}-t(1-x) & \text { for MNC goods }\end{cases}
$$

In the case of acquisition, the net utility of a consumer located at $x$ is

$$
U=s-p_{F}-t x
$$

When the market size is sufficiently large, each firm can set the price level according to its best response posture towards its rival. Markets with insufficient demand may not allow for a best response, in which case firms simply revert to maximizing monopoly profits.

In large and intermediate markets, profit levels of the local firm and the MNC under the MNC's entry are represented by

$$
\begin{gathered}
\pi_{L}\left(p_{L}, p_{F}\right)=\left(p_{L}-c_{L}\right)\left(p_{F}-p_{L}+t\right) / 2 t \\
\pi_{F}\left(p_{L}, p_{F}\right)=\left(p_{F}-c_{F}\right)\left(p_{L}-p_{F}+t\right) / 2 t-I k
\end{gathered}
$$

\footnotetext{
${ }^{6}$ Since linear transportation costs rule out pure-strategy price equilibria when firms locate inside the interval (Tirole p.280), we focus only on the tractable case where both firms locate at the extreme end of the line.
} 
where $I$ is the indicator function set to unity only when the MNC engages in FDI. The associated equilibrium prices are $p_{L}=\left(2 c_{L}+c_{F}+3 t\right) / 3$ and $p_{F}=\left(2 c_{F}+c_{L}+3 t\right) / 3$ in large markets, and $p_{L}=s-\left(c_{F}-c_{L}+3 t\right) / 6$ and $p_{F}=s-\left(c_{L}-c_{F}+3 t\right) / 6$ for intermediate markets where firms' prices are restricted by demand.

When markets are too small to allow for a best response, the local firm engages in monopolistic pricing while the MNC sets its price level to cover the residual markets. This yields profits of

$$
\begin{gathered}
\pi_{L}\left(p_{L}\right)=\left(p_{L}-c_{L}\right)\left(s-c_{L}\right) / 2 t \\
\pi_{F}\left(p_{L}, p_{F}\right)=\left(p_{F}-c_{F}\right)\left(2 t+c_{L}-s\right) / 2 t-I k
\end{gathered}
$$

which are associated with prices $p_{L}=\left(s+c_{L}\right) / 2$ and $p_{F}=\left(3 s-2 t-c_{L}\right) / 2 .^{7}$

If the $\mathrm{MNC}$ acquires the local firm, the local firm's disposition proceeds are equal to (3), while the MNC's acquisition profits are given by the levels attained from monopolizing the market minus the purchasing price of the local firm. Appendix 1 provides profit levels for each entry mode as a function of market size and competition.

\section{Optimal Entry: FDI, Trade or Acquisition}

The MNC's entry decision depends on the relative profitability of FDI, trade and acquisition. Given the demand derived from (1), (2) and the general profit levels in (3) and (3a), we can derive the equilibrium profit level for both firms as a function of entry

\footnotetext{
${ }^{7}$ Two general observations are in order. First, in the case of a local monopoly, profit maximization implies that the local firm may not cover market demand. Once the MNC enters the market, however, the entire market will be covered. Second, for $\mathrm{c}_{L} \geq s$, the local firm will not enter the market because of negative profits.
} 
modes, FDI fixed costs, market sizes, tariffs/transport costs, and degrees of competition between firms.

\subsection{Competition and Entry Modes}

The optimal entry decisions can be conveniently distinguished by the degree of competition in the host market. Three cases result: first, sufficiently high competition allow that only one firm can survive, namely the firm with lower marginal costs. In this case, the local firm is always driven out of the market once the MNC enters the market through FDI or trade. ${ }^{8}$ In the second case, which involves high levels of competition, the MNC may or may not be able to drive out the local firm, depending on the level of fixed costs and tariffs. Optimal entry in this case is examined in detail in section 3.1.2 below.

The most interesting analysis is generated by sufficiently weak competition (or strong product differentiation), which allows both firms to remain in the market at all times. In this case, the entry mode is a function of fixed costs, trade/transportation costs and local market size. Market size becomes a decisive factor when firms coexist because aggregate profits increase in $s$. In addition, if markets are sufficiently large, both firms can set goods' prices without demand constraints. For critically small markets, however, the existence of two firms implies that the MNC and the local firm interact strategically to lower prices (and reduce profits) to remain competitive. This case is examined in the next section, 3.1.1.

\footnotetext{
${ }^{8}$ According to appendix $1, \pi_{M}^{I}=c_{L}-c_{M}-t-k$ and $\pi_{M}^{T}=c_{L}-c_{T}-t$ while $\pi_{L}^{I}=\pi_{L}^{T}=0$. Hence, the local firm is always driven out from the market when the MNC enters through FDI or trade. Acquisition is also possible, as the exact entry mode depends in a simple fashion linearly on market size, fixed costs, and trade barriers. For $s>c_{L}+2 t$ the MNC's optimal entry is acquisition if $s>2 c_{L}-c_{M}-\vartheta$. For $s<c_{L}+2 t$ acquisition occurs at $s>c_{L}+2 \sqrt{\left(c_{L}-c_{M}-\vartheta\right) t}$ where $\vartheta=k$ or $\tau+\delta$. When market size falls below the critical value for each case, the MNC enters only through FDI or trade, depending on the relative magnitudes of $k$ and $\tau+\delta$.
} 


\subsubsection{Entry with Low Degrees of Competition}

Commencing with a low degree of competition $\left(c_{L}-c_{M}\right) / 3 \leq t<c_{L}-c_{M}$, allows us to focus on variations in fixed costs, market size, tariffs, and transport costs as key determinants of the MNC's optimal entry mode. All proofs for this section are relegated to appendix 2. The multitude of entry cases is best summarized in Figures 1-4. Each figure represents combinations of market sizes (vertical axis), fixed costs (horizontal axis) and optimal entry modes (color codes). ${ }^{9}$ Tariff/transport costs increase from Figure 1 to Figure 4. On the axes of the Figures we indicate the threshold market sizes and fixed cost levels associated with changes in entry modes. For example, in the case of low competition and low tariffs (Figure 2) fixed costs higher than the threshold level $k_{4}$ allow for three entry modes: no entry, trade and acquisition, depending on the size of the market. The vertical axis indicates that the MNC never enters markets smaller than $s q$. As soon as the home market is larger than $s 9$, the MNC enters with trade, and once market size $s_{2}$ is superseded, the MNC acquires the domestic firm. All threshold levels are provided in the appendix.

The figures show clear trends. Starting with Figure 1, free trade and proximity to the MNC's foreign production site exclude FDI as a potential entry mode, regardless of market size or fixed costs. No matter whether trade is free or transport costs are negligible, sufficiently large markets always entice an MNC to purchase the local firm, not only to become the monopoly producer, but also because trade is a powerful threat that lowers the acquisition price.

\footnotetext{
${ }^{9}$ We simplify the entry mode representation further by assuming $\mathrm{c}_{T}<\mathrm{c}_{L}+t$.
} 
In Figure 2, the case of low tariffs and transport costs, FDI replaces trade under low fixed costs. This represents the MNC's marginal cost advantage for FDI relative to trade in countries that impose small fixed costs and moderate tariffs. As fixed costs rise, the profitability of FDI diminishes and the MNC resorts to acquisition for large markets, trade in intermediate markets, and no entry in small markets. Neither acquisition nor trade is attractive in small markets because insufficient demand depresses prices to the degree that tariffs or acquisition costs cannot be covered. Interestingly, as fixed costs rise, trade emerges first in large markets. This is because the marginal cost advantage of FDI becomes less significant in large markets where MNCs can set prices without demand constraints. As the market size declines, the price pressures increase, reducing the likelihood that the MNC can cover its costs under tariffs. Rising fixed costs, however, increase the threshold market size for FDI. As in Figure 1, very large markets are covered by acquisition since the MNC can use FDI (for small fixed costs) and trade (under high fixed costs) as threats to reduce the purchasing price.

For high tariffs and transport costs, Figure 3 indicates that the entry mode shifts strongly in favor of acquisition and FDI. Trade disappears first from small markets, where price pressures highlight the importance of low marginal costs. Weak levels of competition thus permit all three entry modes to remain viable, even when high tariffs or transport costs render the MNC's marginal cost greater than the local firm's. At the same time, this regime highlights the importance of entry threats. As rising fixed costs render FDI no longer viable, and since trade is unprofitable due to high tariffs and transport costs, the model predicts that acquisition is the dominant entry mode. Following the pattern in Figure 2, FDI disappears in smaller markets because low prices cannot cover 
progressively rising fixed costs. In large and intermediate markets, acquisition profits soon outweigh trade profits because FDI is still an entry threat when fixed costs are relatively low. As the FDI entry threat disappears, trade and acquisition via trade threats remain the only entry modes. As above, trade is only viable in sufficiently large markets with sufficiently high prices.

Figure 4 replicates the case of prohibitive tariffs and transport costs, which render a degenerate choice between FDI, acquisition, or no entry to the MNC. The triangular shape of FDI has two reasons. First, the increasing fixed costs command higher prices, which are not attainable in relatively small markets. Secondly, in very large markets FDI is less profitable than acquisition which delivers monopoly power as the simple FDI threat sufficiently reduces the acquisition price. High fixed costs and tariffs thus insulate a country from entry by the MNC. As was pointed out by Mueller (2001), very large markets cannot be covered by acquisition with prohibitive trade and investment barriers because neither FDI nor trade can be used as an entry threat.

\subsubsection{Optimal Entry with High Levels of Competition}

The previous section assumes that competition is sufficiently low to sustain both firms at all times. As we increase the level of competition, however, the MNC's marginal cost advantage can drive out the domestic firm. We utilize the same format as above to summarize the entry modes for high competition levels as a function of tariffs and transport costs in Figures 5-8. Proofs are provided in appendix 3.

Compared to Figures 1-4, increased competition invokes more aggressive entry behavior on the part of the MNC in the target market. High competition, Figures 5-8 generates a similar overall trend as in the low competition cases (Figures 1-4). While the 
evolution of the entry pattern is similar, closer comparison reveals important differences. A comparison between appendix 2 and appendix 3 reveals that the threshold magnitudes, which denote trade, acquisition, FDI, and no entry, differ significantly. Intuitively, the fundamental difference between the two cases is that under high degrees of competition FDI becomes a powerful tool to drive the local firm out of the market.

In small markets, greater competition allows the foreign firm to better take advantage of its lower marginal costs. This now allows FDI even in small markets (in Figures 6-8 vs. Figures 2-4) since FDI may now capture the entire market, to generate sufficient demand to cover fixed costs. By the same reasoning, increased competition raises the FDI acquisition threat. This lowers the acquisition threshold market size and allows for acquisition even in small markets (only if fixed costs are sufficiently high to rule out FDI). As tariffs and transport costs rise in Figures 5-8, the export option retreats in the same pattern and for the same reason as in Figures 1-4.

\subsection{Data on Entry into Transition Economies}

Charting Wooster's (2002) data of U.S. MNCs' entry modes across transition countries and across time in Figures 9 and 10 yields support for a number of predictions of the model. ${ }^{10}$ Figure 9 shows the prevalence of entry modes over time, while Figure 10 ranks countries by GDP (increasing from left to right). The data provides support for the implication that market size and acquisition are positively related - with the clear exception of Ukraine and Russia. If the latter two countries are ignored, the correlation

\footnotetext{
${ }^{10}$ Wooster's data examines the entry decisions of 217 US corporations undertaking 491 projects. Her data separates between different entry modes such as pure acquisition FDI, non-FDI related export sales, and new FDI (joint venture financed and new plants). Exports refer only to shipments from the US corporation to the target country. The dataset is large relative to comparable studies; e.g., Lankes and Venables feature 117 companies with 145 projects.
} 
between market size and acquisition is .8 , and if Ukraine is included the correlation drops to .68 . It is tempting to speculate that these two very large economies lack the predicted amount of acquisition because of the absence of the rule of law. Liberalization indicators for the two countries are below the sample average (see de Melo et al 1996 and IMF 2000). While there is no correlation between FDI and market size, exports and market size are strongly correlated with a .84 correlation coefficient. The model predicts that in relatively protected economies, especially for intermediate fixed costs, trade will increase with market size.

Strong support for our model is also provided by the analysis of the relatively small markets. With the exception of Armenia and Kyrgyzstan, all of the small markets are served by exports (the establishment of sales offices). The next most popular entry mode in small markets is FDI; acquisitions are rare in small countries, which is consistent with our model of low competition in the face of moderate fixed costs to FDI.

During the early stages of transition trade costs fell significantly. Since then, trade costs have never been thought to inhibit commerce more than the absence of institutions. Hence, the most commonly used liberalization index includes both tariffs and institutional variables. As we examine the entry modes over time, as trade costs fall largely across countries, and as the above-mentioned liberalization indices increase in all countries, FDI is initially significantly more attractive. Later exports begin to dominate. 


\section{Figure 9}

\section{Transition Economies' Composition of U.S. MNCs' Entry Modes}

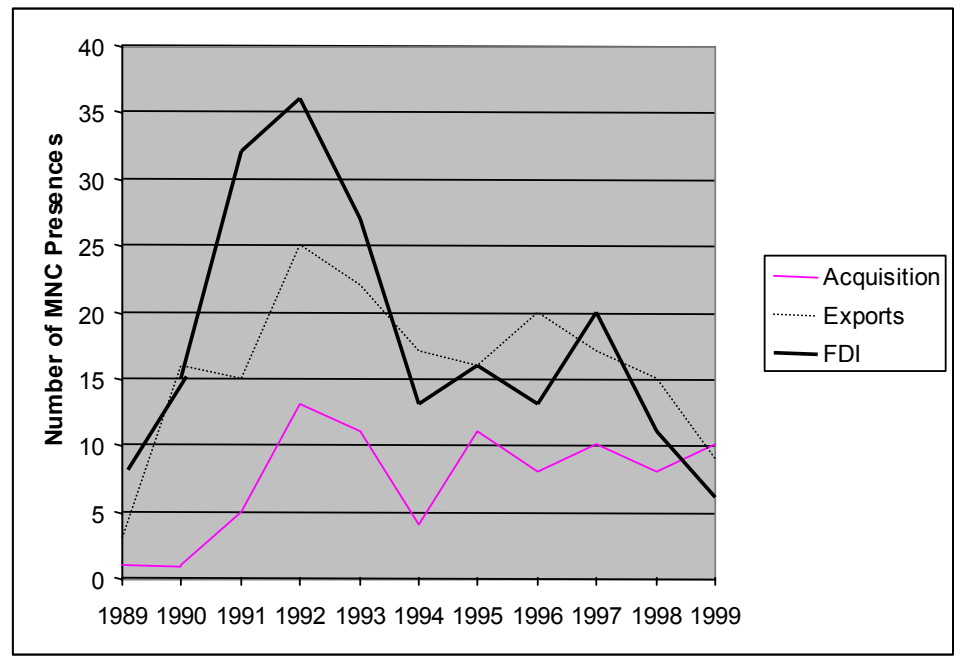

Source: Wooster's (2002)

\section{Figure 10}

\section{U.S. MNC's Entry Mode (1988-1999)}

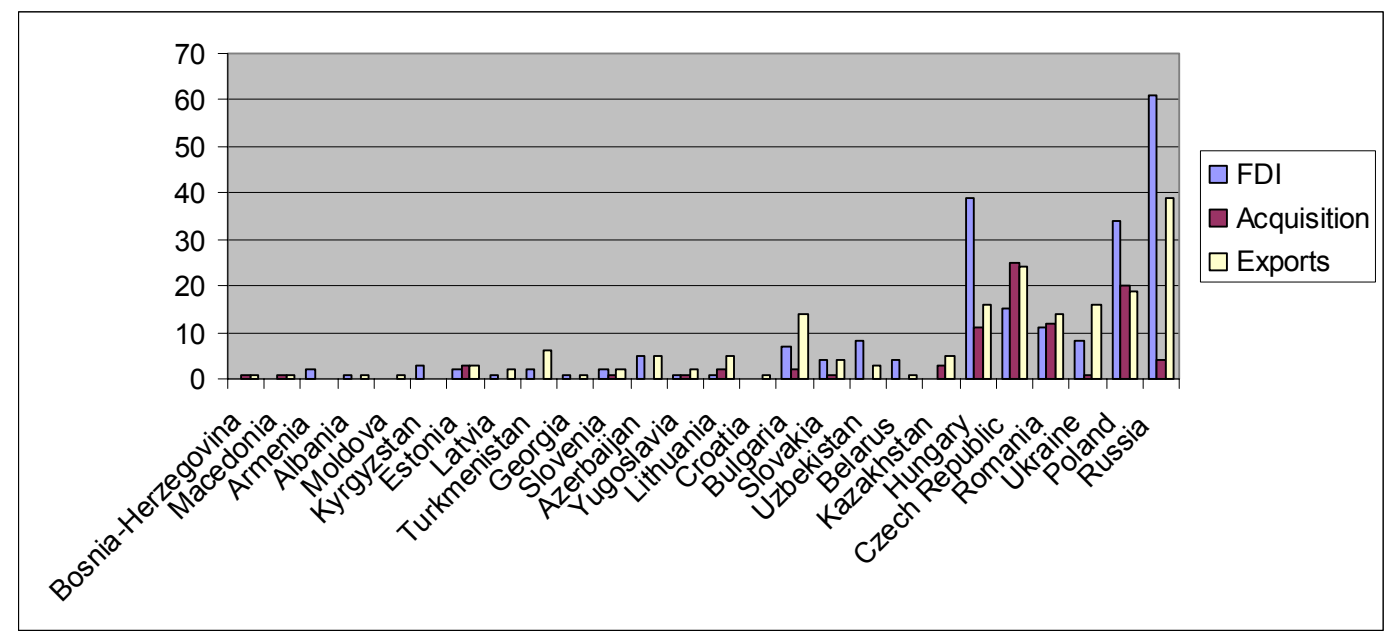

Source: Wooster's (2002) 
The data is presented simply to provide a general idea of the pattern of FDI in transition economies. Even though the sample is large compared to other transition studies, there are a number of reasons in the real world and in the model that determine the entry behavior. The degree of competition for each firm is not known, but it plays a crucial role in the model. Also, the exact degree of trade costs is impossible to ascertain, although liberalization indices are available which combine both tariff costs and country specific institutional fixed costs.

\section{Trade Policy and Welfare}

\subsection{Tariffs and Firm Welfare}

It is natural to inquire to what degree trade and tariffs help or hurt both the domestic firm and the MNC. Clearly, the MNC is better off whenever it chooses trade over FDI. Tariffs, on the other hand, reduce the profitability of exports and reduce the MNC's market demand. Hence, tariffs are unambiguously profit-reducing for the MNC.

Clearly, trade decreases welfare for the local firm as the move from prohibitive tariffs to free trade increases competition, lowers market demand for the domestic good and reduces the good's price. For these reasons, the domestic firm will lobby for protection.

There exists, however, a possibility for the local firm to benefit from trade. Moving from prohibitive to positive tariffs, an MNC might find it profitable to forgo FDI with high fixed costs and export instead. Since the MNC and the local firm engage in a pricing game, the goods are strategic complements. The MNC's switching from FDI to trade (under positive tariffs) in the face of strategic complementarity implies that the domestic price increases. This generates a net benefit to the local firm if the loss in market share is offset by a sufficiently large price increase. 


\subsection{Endogenous Trade Policy}

Thus far, we have focused on the local firm's profit levels in response to exogenously set tariffs. The tariff itself can be seen as a policy variable, as shown by voluminous endogenous protection literature (Hillman, 1982; Findlay and Wellisz, 1982; Magee Brock and Young, 1989; and Grossman and Helpman, 1994, 1996). In this section, we examine the factors that determine an endogenous tariff to maximize local interest groups' welfare levels and to influence the MNC's entry mode.

We follow Hillman's (1982) approach to tariff formation by stipulating a political support function, $W\left(\pi_{L}, C\right)$, which consists of domestic firm's profits, $\pi_{L}$, and net consumer surplus, $C .^{11}$ In the political support approach to tariff formation, the government trades off political support from consumers against higher industry profits. Support for the government from industry increases in tariffs and in industry's profits, while consumers increase their support when product prices decline. Much like in Staiger and Tabellini (1987), the government does not have a self-interested motive other than redistribution to minimize the loss to either constituency; tariffs revenue is redistributed lump sum.

It is thus possible to interpret the model as one in which an altruistic government chooses a tariff to maximize aggregate support from its constituents. The literature on endogenous tariff formation has also included government preferences over contributions/bribes, which may be especially relevant for transition economies. Empirical estimates of government weights on non-altruistic components in its objective function turn out to be extremely low (see Gawande and Bandyopadhyay 2000, Goldberg

\footnotetext{
${ }^{11}$ We assume that $W[$.$] is well-behaved, i.e., W_{\pi_{L}}>0 ; W_{c}>0, W_{\pi_{L} \pi_{L}}<0, W_{c c}<0$, and $W_{\pi_{L} C}=0$
} 
and Maggi 1999, and Eicher and Osang 2002). For simplicity we abstract from bribery and contributions below, so that the government maximizes political support by choosing a tariff that maximizes the political support function, or

$$
\frac{d W}{d \tau}=\frac{d \pi_{L}}{d \tau} W_{\pi_{L}}+\frac{d C}{d \tau} W_{C}=0
$$

where $W_{x}=\partial W / \partial x$.

The domestic firm's profits are derived as above and consumer welfare is derived from the fact that $x$ consumers derive utility $s-p_{L}-t x$ from the domestic good and $1-x$ consumers achieve utility $s-p_{F}-t(1-x)$ by consuming the MNC's good. Hence, net consumer surplus

$$
\int_{i=0}^{x}\left(s-p_{L}-t i\right) d i+\int_{i=x}^{1}\left(s-p_{F}-t(1-i)\right) d i=s+p_{F}(x-1)-.5 t-t x^{2}+\left(t-p_{L}\right) x
$$

depends critically on the size of the market. We differentiate between large and intermediate market size to determine the optimal tariff as the government maximizes its political support. ${ }^{12}$

\subsubsection{Large Market Size}

Appendix 4 proves that in sufficiently large markets, $\left(c_{L}+c_{T}+3 t\right) / 2 \leq s$, the government sets the optimal tariff according to

$$
\tau^{*}=\frac{3\left(3 \varepsilon_{\pi, C}-2\right) t}{\left(\varepsilon_{\pi, C}+2\right)}+c_{L}-c_{F}-\sigma
$$

\footnotetext{
${ }^{12}$ Small markets do not entail interesting strategic firm behavior in the Hotelling setup; hence the literature has traditionally considered markets that are sufficiently large to generate strategic behavior. We follow Verboven (1998) and others as we neglect this case.
} 
where $\varepsilon_{\pi C}$ is the marginal rate of transformation between profits and net consumer surplus in the government's welfare function, which increases the tariff. Fortunately the empirical literature provides good guidance that governments' weights on consumer welfare are always significantly larger than their consideration of firm benefits from protection (see Gawande and Krishna (forthcoming) for a survey). Hence we examine $\varepsilon_{\pi C}<1$ as the only relevant case.

The tariff increases in the marginal cost of the local firm, $c_{L}$, rendering the government more likely to protect inefficient local firms that face stronger cost competition from abroad. In the same vein, the tariff increases as the MNC's marginal cost and transport costs fall to protect profits of the local firm. The tariff level is discontinuous in the degree of monopoly power. Tariffs are positively (negatively) related to the monopoly power for high (low) levels of $\varepsilon_{\pi C} \cdot{ }^{13}$ Monopoly power provides the local firm with a greater ability to raise prices (and profits) in response to tariffs. Hence a tariff is attractive for the government in this case. If the government is, however, significantly more interested in consumer surplus than firm profits, it will lower the tariff even for monopolistic industries, in order to encourage competition from the MNC. Note that whenever the tariff increases, the MNC's choice of entry mode is impacted as analyzed in section 3 .

\subsubsection{Intermediate Market Size}

For intermediate market sizes, $\left(2 c_{L}+c_{T}+3 t\right) / 3 \leq s<\left(c_{L}+c_{T}+3 t\right) / 2$, appendix 4 proves the endogenous tariff to be

\footnotetext{
${ }^{13}$ The critical level of $\varepsilon_{\pi, C}$ is $2 / 3$.
} 


$$
\tau^{*}=\frac{\left(\varepsilon_{\pi, C}\left(3 s-2 c_{L}-3 t\right)-c_{L}\right)}{\left(\varepsilon_{\pi, C}-1\right)}-c_{F}-\sigma
$$

Here the comparative statics are similar to the large market case, with two notable exceptions. First and foremost, market size matters in intermediate markets, because the $\mathrm{MNC}$ and the local firm are constraint in their price movements by demand. Secondly, the tariff decreases in the market size, as the government has a stronger incentive to lower trade barriers for larger markets, to the benefit of consumers' surplus. The tariff function then implies that expanding market size should lead to freer trade. In contrast to the large markets, tariffs now increase unambiguously in monopoly power since price pressures, due to constraint market demand, curbs the local firm's ability to raise prices after having been awarded a tariff. This renders the government concerned about protecting the consumers' welfare. As in the large market case, tariffs increase in local firms' marginal costs and decrease in the MNC's marginal and transport costs.

\section{Concluding remarks}

We investigate how MNCs' optimal entry modes depend on the market size, on fixed costs of FDI, tariffs/transport costs and on competition. Consistent with the results of previous research in this area, we show that low trade barriers favor international trade over other entry options on the part of the MNC. As trade barriers increase, however, we find that trade becomes viable only in intermediate sized markets. For insufficient market demand, depressed price levels render it less likely that the MNC can overcome trade barriers. Instead, FDI can subsist in those markets due to the MNC's advantage in 
production cost over the local firm. High fixed investment costs increase the threshold market size for FDI, which cannot be offset unless trade barriers are sufficiently low to allow for the MNC's export penetration.

With sufficiently high trade barriers, the MNC favors acquisition over trade as long as FDI fixed costs are not too large to allow for FDI as an entry threat. Moreover, large markets give rise to acquisition, independent of trade barriers, because the monopoly power derived from acquisitions pays handsomely in very large markets. When we consider the case of high competition, FDI becomes the predominant entry mode, which allows the MNC's to exploit the full benefits of its ownership advantage.

Analyzing the welfare implications of the entry modes, we show that trade barriers protect the local firm's welfare at the expense of MNC profits. Hence, the MNC will pursue free international trade while the local firm will seek high protection from its government. One interesting result, stemming from the strategic complementarity between domestic and import goods, is that the local firm may attain higher profits under trade with protection than under MNC's FDI entry. This leads us to investigate the incentives of policy makers who set tariffs endogenously in order to maximize welfare and influence specific MNC entry modes. We show that an endogenous tariff that maximizes a government's political support increases in the marginal cost of the local firm and decreases in the level of competition between firms. 


\section{References}

Brouthers, K. D., Brouthers L. E., 2001. Explaining the National Cultural Distance Paradox. Journal of International Business Studies 32(1), 177-189.

Brouthers, K. D., Brouthers L. E., Werner S., 1999. Is Dunning's Eclectic Framework Descriptive or Normative? Journal of International Business Studies 30(4), 831-844.

Buckley, P. J., Casson M. C., 1998. Analyzing Foreign Market Entry Strategies: Extending the Internalization Approach. Journal of International Business Studies 29(3), 539-562.

Collins, S. M., Rodrik D., 1991. Eastern Europe and the Soviet Union in the World Economy, Institute for International Economics working paper 32.

Davis, P. S., Desai A. B., Francis J. D., 2000. Mode of International Entry: An Isomorphism Perspective. Journal of International Business Studies 31(2), 239258.

De Melo M., Cevdet D., Gelb A., 1996. Patterns of Transition from Plan to Market," World Bank Economic Review, 10 (3), 397-424.

Dunning, J.H., 1981, International Production and the Multinational Enterprise. London: G. Allen and Unwin.

Ethier, W. J., 1986. The Multinational Firm. Quarterly Journal of Economics 101(4) 805-834

EBRD, 1994. Transition Report Oxford University Press, (page 130ff).

Eicher, T. S., Osang, T., 2002, Protection for Sale: An Empirical Investigation: A Comment. American Economic Review, 92, 5, 1702-11.

Feenstra, R. C., Hanson, G. H., 1996. Foreign Investment, Outsourcing and Relative Wages. In: Robert C. Feenstra, Gene M. Grossman, and Douglas A. Irwin, eds., Political Economy of Trade Policy: Essays in Honor of Jagdish Bhagwati, Cambridge: MIT Press, pp. 89-127.

Feenstra, R. C., Hanson, G. H., 2001. Intermediaries in Entrepot Trade: Hong Kong Re-Exports of Chinese Goods, NBER Working Paper No. w8088

Findlay, R., Wellisz S., 1982. Endogenous Tariffs, the Political Economy of Trade Restrictions, and Welfare. In: Jagdish Bhagwati (ed.), Import Competition and Response. Chicago: University of Chicago Press.

Gawande, K., Krishna, P., 2003. The Political Economy of Trade Policy: Empirical Approaches. In Handbook of International Trade, James Harrigan, and Kwan Choi eds., Basil Blackwell

Gawande, K., Bandyopadhyay, U., 2000, Is Protection for Sale? Evidence on the Grossman-Helpman Theory of Endogenous Protection. Review of Economics and Statistics 82, 139-52.

Goldberg, P. K., Maggi, G., 1999, Protection for Sale: An Empirical Investigation. American Economic Review, 89(5), 1135-1155.

Grossman, G. M., Helpman E., 1994. Protection for Sale. American Economic Review 84(4), 833-850.

Grossman, G. M., Helpman E., 1996. Electoral Competition and Special Interest Politics. Review of Economics Studies, 63, 265-286. 
Hanson, G., Mataloni R., Slaughter, M. I., 2001. Expansion Strategies of U.S. Multinational Firms. In: Dani Rodrik and Susan M. Collins, eds., Brookings Trade Forum 2001, pp. 245-282.

Helpman, E., 1984. A Simple Theory of Trade with Multinational Corporations. Journal of Political Economy, 92, 451-71.

Helpman, E., 1985. Multinational Corporations and Trade Structure. Review of Economic Studies, 52, 448-58

Henisz, W. J., 2000. The Institutional Environment for Multinational Investment. Journal of Law, Economics and Organization 16(2), 334-364.

Hennart, J. F., Park Y. R., 1993. Greenfield vs. Acquisition: The Strategic Japanese Investors in the United States. Management Science 39(9), 1054-1070.

Hill, C. W.L., Hwang P., Kim W. C., 1990. An Eclectic Theory of the Choice of International Entry Mode. Strategic Management Journal 11, 117-128.

Hillman, A. L. 1982. Declining Industries and Political-Support Protectionist Motives. American Economic Review 72(5), 1180-1187.

Horstmann, I. J. and Markusen, J. R., 1992. Endogenous Market Structure in International Trade. Journal of International Economics 32, pp. 109-129.

IMF, 2000. World Economic Outlook.

Lankes, H. P., Venables A. J., 1996. Foreign Direct Investment in Economic Transition: The Changing Pattern of Investment. Economics of Transition 4(2), 331-347.

Lu, J. W. 2002. Intra- and Inter-organizational Imitative Behavior: Institutional Influences on Japanese Firms' Entry Mode Choice. Journal of International Business Studies, 33(1), 19-37.

Magee, S. P., Brock W. A., Young L., 1989. Black Hole Tariffs and Endogenous Policy Formation. Cambridge, The MIT Press

Markusen, J. R., 1984, Multinationals, Multi Plant Economics and the Grains From Trade Journal of International Economics, 16, 205-26.

Markusen, J. R., 1995. The Boundaries of Multinational Enterprises and the Theory of International Trade. Journal of Economic Perspectives 9(2), 169-189.

Meyer, K. E., 2001. Institutions, Transaction Costs, and Entry Mode Choice in Eastern Europe. Journal of International Business Studies 32(2), 357-367.

Meyer, K. E., Estrin S. 2001. Brownfield Entry in Emerging Markets. Journal of International Business Studies 32(3), 575-584.

Motta, M. 1992. Multinational Firms and the Tariff-Jumping Argument: A Game Theoretic Analysis with some Unconventional Conclusions. European Economic Review, 36, 1557-71

Mueller, T., 2001. Analyzing Modes of Foreign Entry: Greenfield Investment versus Acquisition. University of Munich, mimeo

Shenkar, O., 2001. Cultural Distance Revisited: Towards a More Rigorous Conceptualization and Measurement of Cultural Differences. Journal of International Business Studies 32(3), pp. 519-535.

Smarzynska, B., 2000. Technological Leadership and the Choice of Entry Mode by Foreign Investors. World Bank Policy Research Working Paper 2314 
Siripaisalpipat, P., Hoshino Y., 2000. Firm-Specific Advantages, Entry Modes, and Performance of Japanese FDI in Thailand. Japan and the World Economy 12(1), 33-48.

Staiger, R., Tabellini G., 1987. Discretionary Trade Policy and Excessive Protection. American Economic Review 77, 340-348.

Tirole, J., 1988. The Theory of Industrial Organization (p. 280). Cambridge MIT Press UN, 1999. Trade and Development Report. Oxford: Oxford Press.

Verboven, F., 1998, Localized Competition, Multimarket Operation, and Collusive Behavior. International Economic Review, 39(2), 371-398.

Wooster, R., 2002 Consequences for Shareholder Wealth From Expansion in Transition Economies: Evidence From The U.S. Stock Market. University of Oregon, Mimeo.

World Bank, 1999. Transition Newsletter, Summer.

World Bank, 2002. World Development Report, Oxford Press 
Figure 1

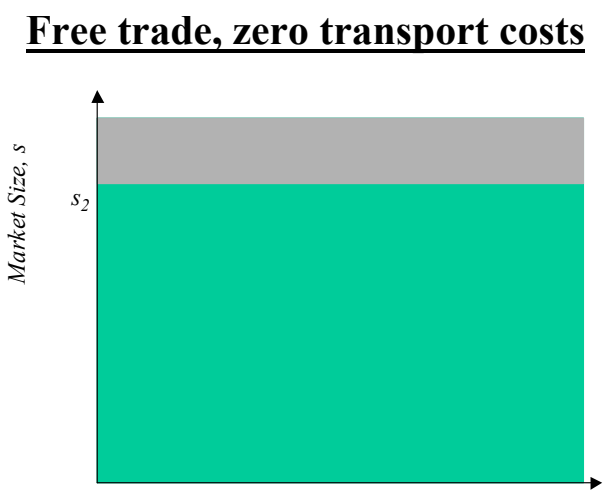

Fixed Costs, $k$

Figure 3

$\underline{\text { High tariffs and transport costs }}$

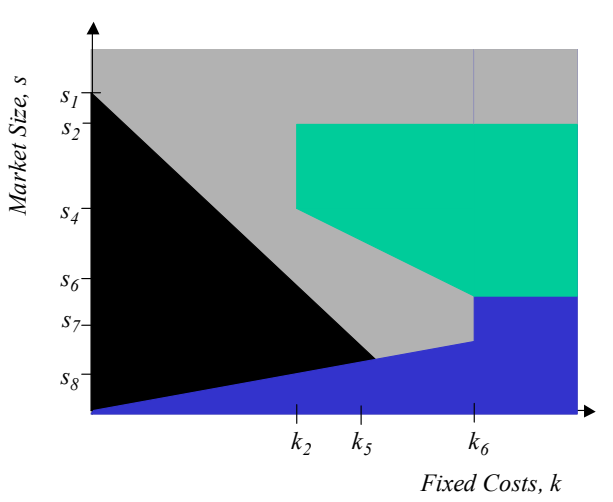

Figure 2

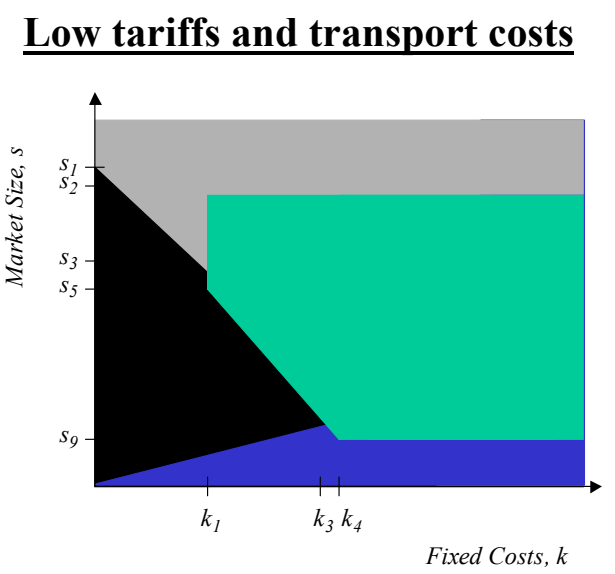

Figure 4

\section{$\underline{\text { Prohibitive tariffs and transport costs }}$}

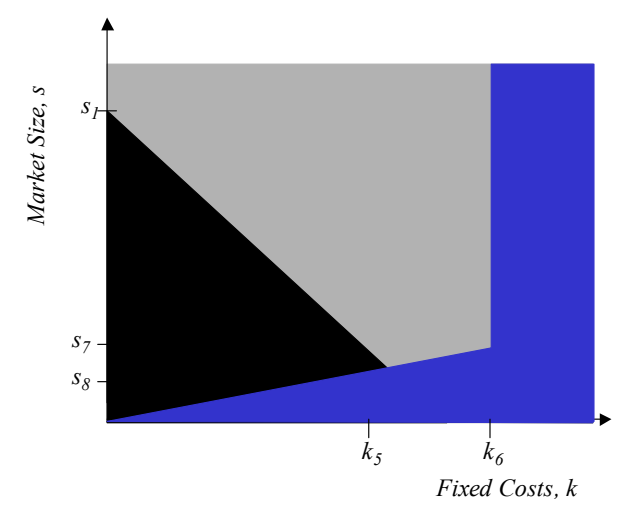

Legend: Trade: $\square$; Acquisition: $\square$; FDI: $\square$; No Entry: 
Figure 5

\section{Free trade, zero transport costs}

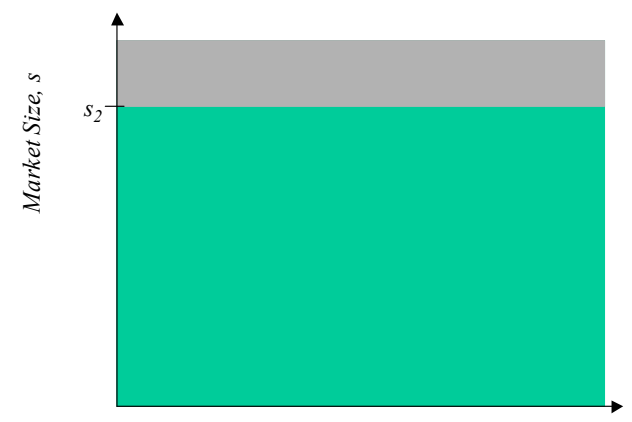

Fixed Costs, $k$

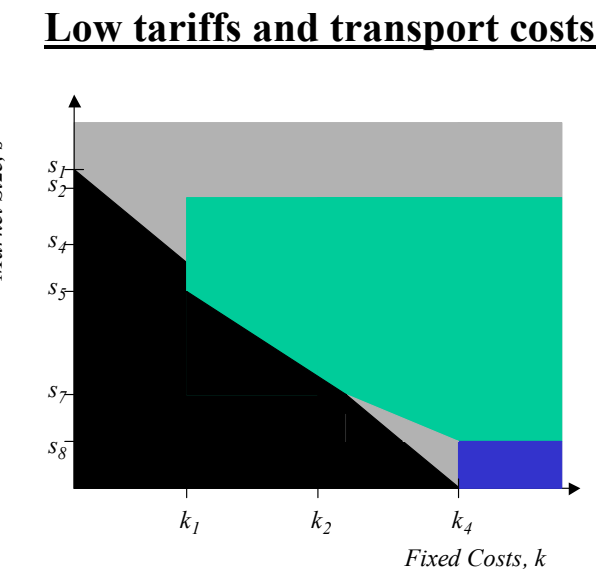

Figure 8

$\underline{\text { Prohibitive tariffs and transport costs }}$

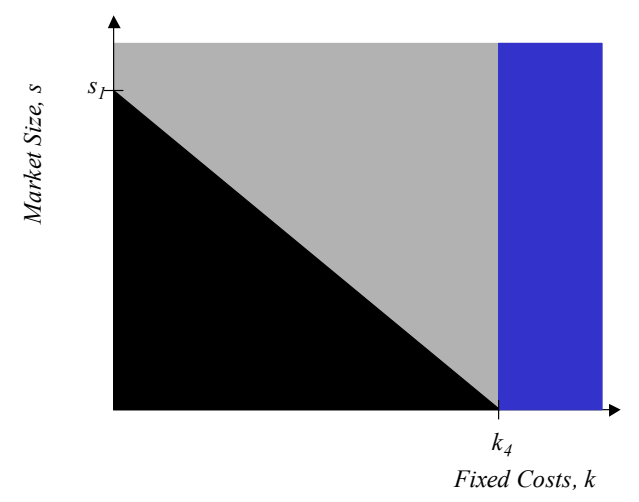




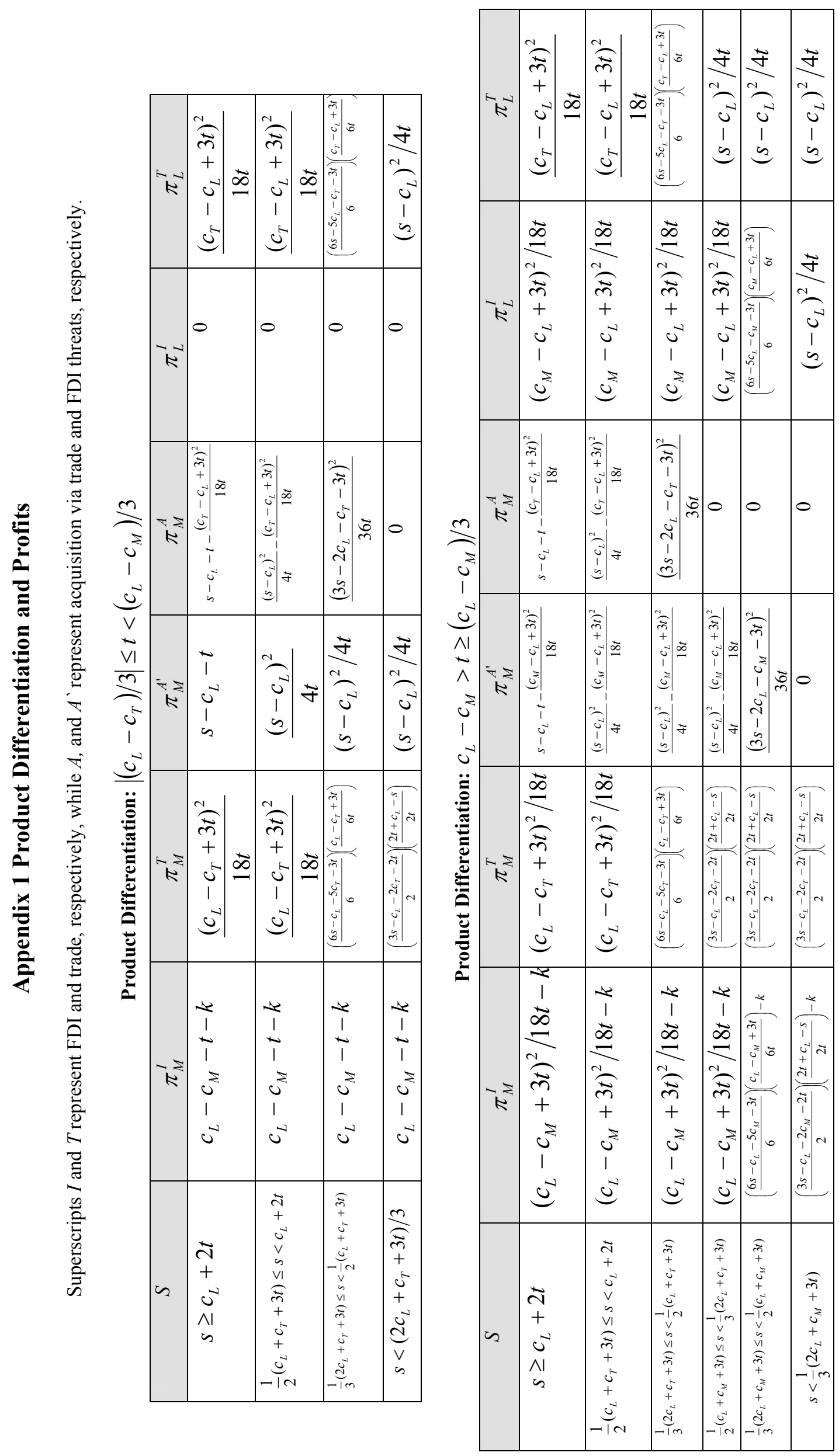



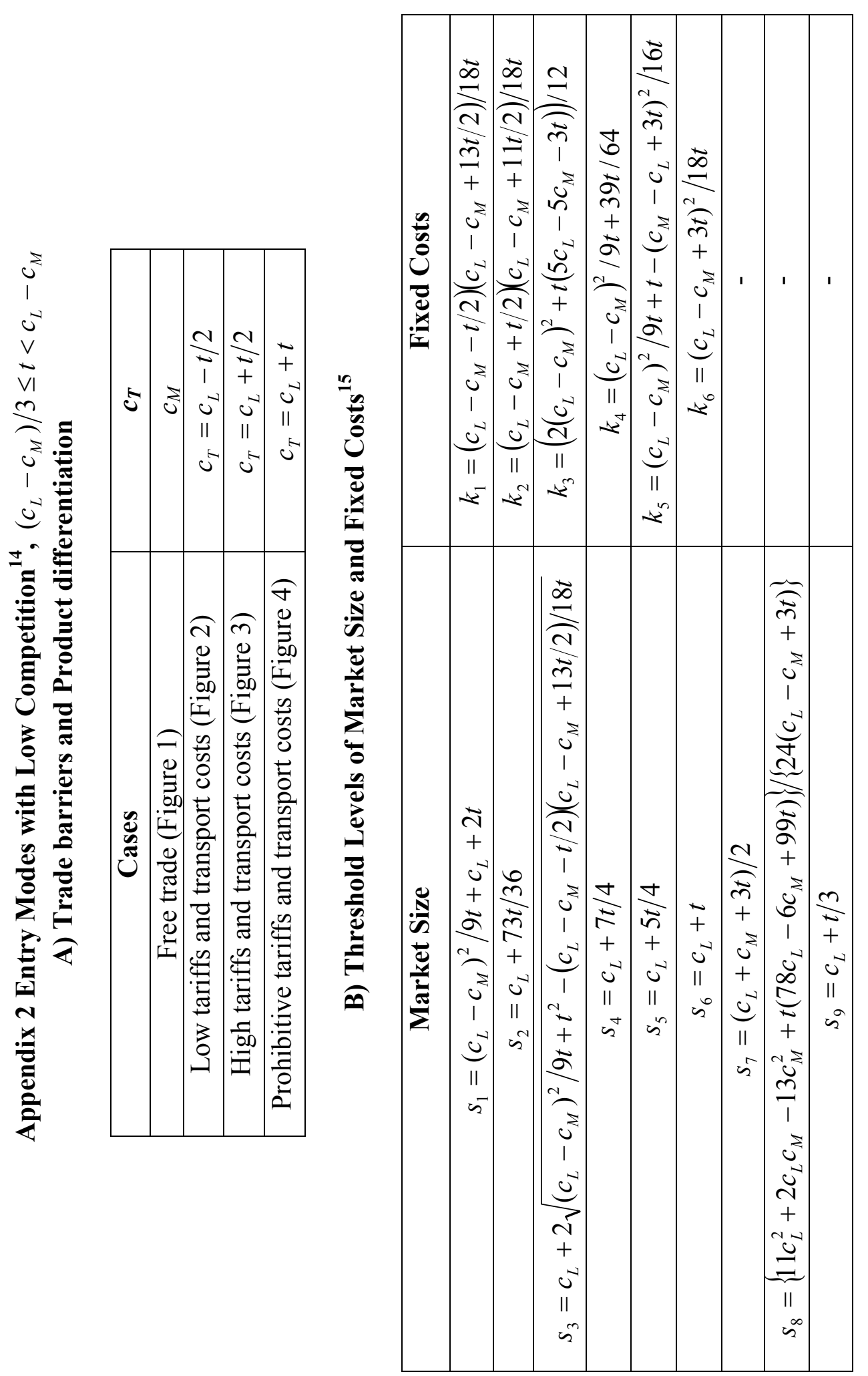

룽. 잏

क力: 氙

兽远

융

수 웡

ठ⿹

焉泀员

표.

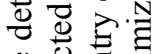

光

品包

d)

궁 岂

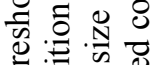

当: ⿹气

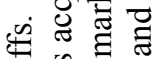

可记

. $\sum \sum \pm$

들

을 졿

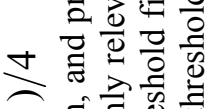

₹ क्ष

ט.

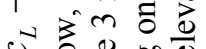

능

ソ

ฟI

$\stackrel{0}{2} \stackrel{0}{0}$

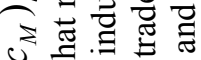

1 車恶进

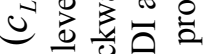
๖ั

\& \& ज ब 至

ఏ छ

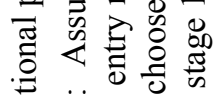

:

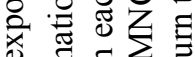

कै

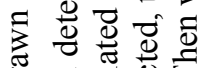

흥 흥

근

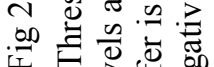

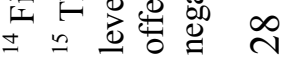



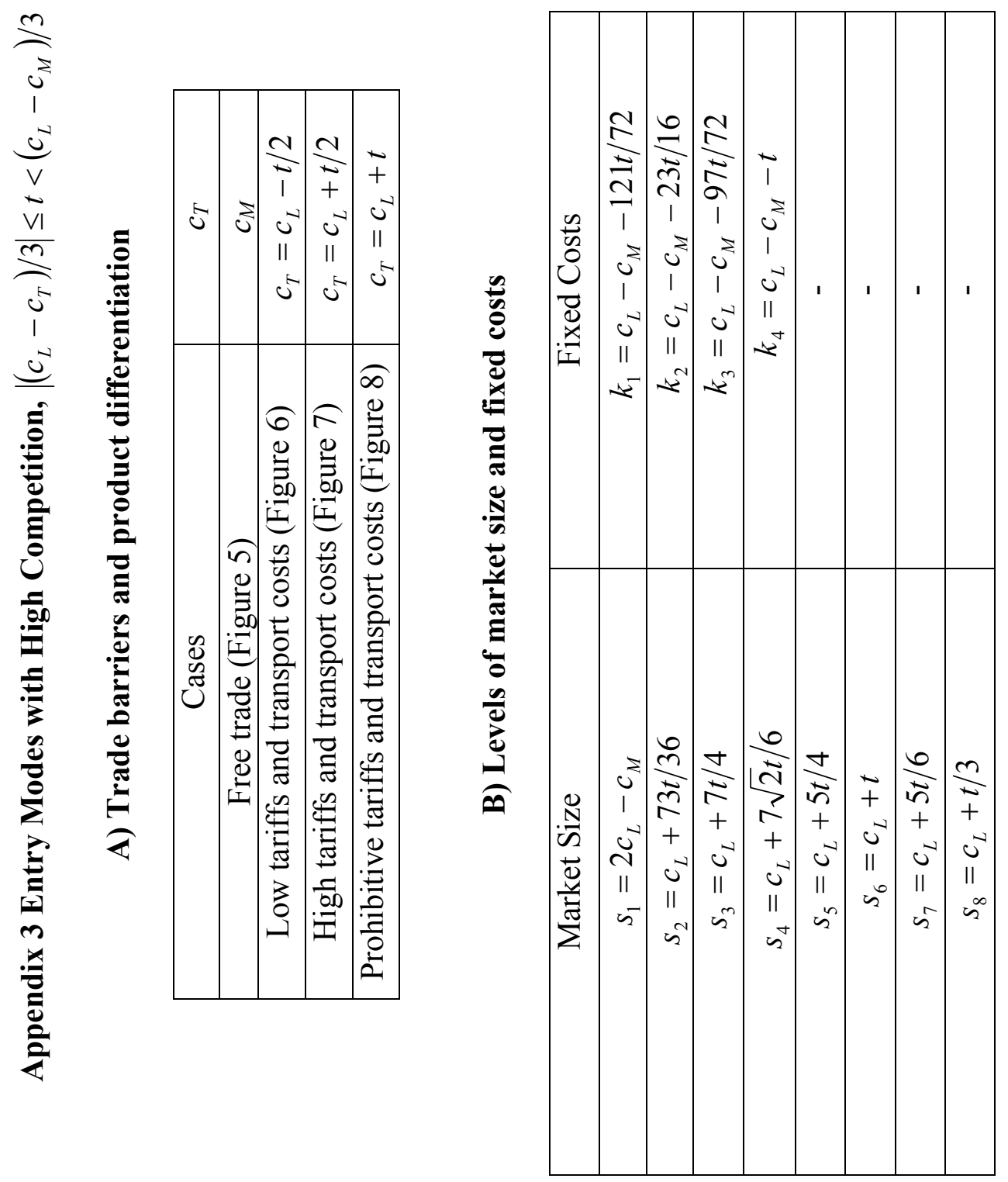


\section{Appendix 4}

\section{Endogenous Tariffs}

\section{A) Endogenous Tariff in Large Markets}

Substituting profits $\pi_{L}=\left(c_{T}-c_{L}+3 t\right)^{2} / 18 t$, consumer surplus $C=s+p_{F}(x-1)-.5 t-t x^{2}+\left(t-p_{L}\right) x$, equilibrium demand $x=\left(p_{F}-p_{L}+t\right) / 2 t$, and equilibrium prices $p_{L}=\left(2 c_{L}+c_{T}+3 t\right) / 3$, $p_{F}=\left(2 c_{T}+c_{L}+3 t\right) / 3$, in the political support function the government's optimization yields

$$
\frac{d W}{d \tau}=\partial W / \partial \pi_{L}\left(c_{F}+\tau+\sigma-c_{L}+3 t\right) / 9 t+\partial W / \partial C\left(c_{F}+\tau+\sigma-c_{L}-9 t\right) / 18 t=0
$$

Assuming a constant marginal rate of transformation, $\varepsilon_{\pi, C}=-\left(d \pi_{L} / d \tau\right) /(d C / d \tau)$, we can solve for the tariff function $\tau^{*}=3\left(3 \varepsilon_{\pi, C}-2\right) t /\left(\varepsilon_{\pi, C}+2\right)+c_{L}-c_{F}-\sigma$.

\section{B) Endogenous Tariffs in Intermediate Markets}

In the intermediate sized markets, local profits change to $\pi_{L}=\left(\left(6 s-5 c_{L}-c_{T}-3 t\right) / 6\right)\left(c_{T}-c_{L}+3 t / 6 t\right)$, generating equilibrium prices $p_{L}=s-\left(c_{T}-c_{L}+3 t\right) / 6, \quad p_{F}=s-\left(c_{L}-c_{T}+3 t\right) / 6$. The maximization of the political support function then yields

$$
\frac{d W}{d \tau}=\partial W / \partial \pi_{L}\left(3 s-2 c_{L}-c_{F}-\tau-\sigma-3 t\right) / 18 t+\partial W / \partial C\left(c_{F}+\tau+\sigma-c_{L}\right) / 18 t=0
$$

to yield the tariff function $\tau^{*}=\left(\varepsilon_{\pi, C}\left(3 s-2 c_{L}-3 t\right)-c_{L}\right) /\left(\varepsilon_{\pi, C}-1\right)-c_{F}-\sigma$ 


\section{CESifo Working Paper Series}

(for full list see www.cesifo.de)

1109 Stephen Nickell, Employment and Taxes, December 2003

1110 Stephan Sauer and Jan-Egbert Sturm, Using Taylor Rules to Understand ECB Monetary Policy, December 2003

1111 Sascha O. Becker and Mathias Hoffmann, Intra-and International Risk-Sharing in the Short Run and the Long Run, December 2003

1112 George W. Evans and Seppo Honkapohja, The E-Correspondence Principle, January 2004

1113 Volker Nitsch, Have a Break, Have a ... National Currency: When Do Monetary Unions Fall Apart?, January 2004

1114 Panu Poutvaara, Educating Europe, January 2004

1115 Torsten Persson, Gerard Roland, and Guido Tabellini, How Do Electoral Rules Shape Party Structures, Government Coalitions, and Economic Policies? January 2004

1116 Florian Baumann, Volker Meier, and Martin Werding, Transferable Ageing Provisions in Individual Health Insurance Contracts, January 2004

1117 Gianmarco I.P. Ottaviano and Giovanni Peri, The Economic Value of Cultural Diversity: Evidence from US Cities, January 2004

1118 Thorvaldur Gylfason, Monetary and Fiscal Management, Finance, and Growth, January 2004

1119 Hans Degryse and Steven Ongena, The Impact of Competition on Bank Orientation and Specialization, January 2004

1120 Piotr Wdowinski, Determinants of Country Beta Risk in Poland, January 2004

1121 Margarita Katsimi and Thomas Moutos, Inequality and Redistribution via the Public Provision of Private Goods, January 2004

1122 Martin Peitz and Patrick Waelbroeck, The Effect of Internet Piracy on CD Sales: CrossSection Evidence, January 2004

1123 Ansgar Belke and Friedrich Schneider, Privatization in Austria: Some Theoretical Reasons and First Results About the Privatization Proceeds, January 2004

1124 Chang Woon Nam and Doina Maria Radulescu, Does Debt Maturity Matter for Investment Decisions?, February 2004 
1125 Tomer Blumkin and Efraim Sadka, Minimum Wage with Optimal Income Taxation, February 2004

1126 David Parker, The UK's Privatisation Experiment: The Passage of Time Permits a Sober Assessment, February 2004

1127 Henrik Christoffersen and Martin Paldam, Privatization in Denmark, 1980-2002, February 2004

1128 Gregory S. Amacher, Erkki Koskela and Markku Ollikainen, Deforestation, Production Intensity and Land Use under Insecure Property Rights, February 2004

1129 Yin-Wong Cheung, Javier Gardeazabal, and Jesús Vázquez, Exchange Rate Dynamics: Where is the Saddle Path?, February 2004

1130 Alberto Alesina and Guido Tabellini, Bureaucrats or Politicians?, February 2004

1131 Gregory S. Amacher, Erkki Koskela, and Markku Ollikainen, Socially Optimal Royalty Design and Illegal Logging under Alternative Penalty Schemes, February 2004

1132 David M. Newbery, Privatising Network Industries, February 2004

1133 Charles Yuji Horioka, The Stagnation of Household Consumption in Japan, February 2004

1134 Eiji Fujii, Exchange Rate Pass-Through in the Deflationary Japan: How Effective is the Yen's Depreciation for Fighting Deflation?, February 2004

1135 Mark M. Spiegel and Nobuyoshi Yamori, Determinants of Voluntary Bank Disclosure: Evidence from Japanese Shinkin Banks, Febrary 2004

1136 Robert Dekle and Kenneth Kletzer, Deposit Insurance, Regulatory Forbearance and Economic Growth: Implications for the Japanese Banking Crisis, February 2004

1137 Takatoshi Ito and Kimie Harada, Bank Fragility in Japan, 1995-2003, February 2004

1138 Kunio Okina and Shigenori Shiratsuka, Policy Duration Effect under Zero Interest Rates: An Application of Wavelet Analysis, February 2004

1139 Francine D. Blau and Lawrence M. Kahn, Do Cognitive Test Scores Explain Higher U.S. Wage Inequality?, February 2004

1140 Michael Rauscher, Economic Growth and Tax-Competing Leviathans, February 2004

1141 Ernst Fehr and Jean-Robert Tyran, Money Illusion and Coordination Failure, February 2004

1142 Ingo Vogelsang, Network Utilities in the U.S. - Sector Reforms without Privatization, March 2004 
1143 Marc-Andreas Muendler, Estimating Production Functions When Productivity Change is Endogenous, March 2004

1144 Sascha O. Becker, Samuel Bentolila, Ana Fernandes, and Andrea Ichino, Job Insecurity and Children's Emancipation, March 2004

1145 Pascalis Raimondos-Møller and Alan D. Woodland, Non-Preferential Trading Clubs, March 2004

1146 Robert Fenge and Matthias Wrede, EU Regional Policy: Vertical Fiscal Externalities and Matching Grants, March 2004

1147 Chi-Yung Ng and John Whalley, Geographical Extension of Free Trade Zones as Trade Liberalization: A Numerical Simulation Approach, March 2004

1148 Marc-Andreas Muendler, Trade, Technology, and Productivity: A Study of Brazilian Manufacturers, 1986-1998, March 2004

1149 Eugene Beaulieu, Vivek H. Dehejia, and Hazrat-Omar Zakhilwal, International Trade, Labour Turnover, and the Wage Premium: Testing the Bhagwati-Dehejia Hypothesis for Canada, March 2004

1150 Giorgio Brunello and Francesca Gambarotto, Agglomeration Effects on EmployerProvided Training: Evidence from the UK, March 2004

1151 S. Brock Blomberg, Gregory D. Hess, and Athanasios Orphanides, The Macroeconomic Consequences of Terrorism, March 2004

1152 Bodo Sturm and Joachim Weimann, Unilateral Emissions Abatement: An Experiment, March 2004

1153 Wolfgang Ochel, Welfare-to-Work Experiences with Specific Work-First Programmes in Selected Countries, March 2004

1154 Jan K. Brueckner and Eric Pels, European Airline Mergers, Alliance Consolidation, and Consumer Welfare, March 2004

1155 Aaron Tornell, Frank Westermann, and Lorenza Martínez, NAFTA and Mexico's Economic Performance, March 2004

1156 George Economides, Sarantis Kalyvitis, and Apostolis Philippopoulos, Do Foreign Aid Transfers Distort Incentives and Hurt Growth? Theory and Evidence from 75 Aidrecipient Countries, March 2004

1157 Robert Fenge and Volker Meier, Are Family Allowances and Fertility-related pensions Siamese Twins?, March 2004

1158 Bruno S. Frey, Simon Luechinger, and Alois Stutzer, Valuing Public Goods: The Life Satisfation Approach, March 2004 
1159 Jerome L. Stein and Guay C. Lim, Asian Crises: Theory, Evidence, Warning-Signals, March 2004

1160 Romain Ranciere, Aaron Tornell, and Frank Westermann, Crises and Growth: A ReEvaluation, March 2004

1161 Assaf Razin and Efraim Sadka, Transparency, Specialization and FDI, March 2004

1162 Ludger Woessmann, How Equal Are Educational Opportunities? Family Background and Student Achievement in Europe and the United States, March 2004

1163 B.M.S. van Praag and Barbara E. Baarsma, Using Happiness Surveys to Value Intangibles: The Case of Airport Noise, March 2004

1164 Aaron Tornell, Frank Westermann, and Lorenza Martínez, The Positive Link Between Financial Liberalization, Growth, and Crises, March 2004

1165 Helge Berger and Carsten Hefeker, One Country, One Vote? Labor Market Structure and Voting Rights in the ECB, March 2004

1166 Clemens Fuest and Martin Kolmar, A Theory of User-Fee Competition, March 2004

1167 Friedrich Schneider and Robert Klinglmair, Shadow Economies around the World: What Do We Know?, April 2004

1168 Horst Raff and Nicolas Schmitt, Exclusive Dealing and Common Agency in International Markets, April 2004

1169 M. Hashem Pesaran and Allan Timmermann, Real Time Econometrics, April 2004

1170 Sean D. Barrett, Privatisation in Ireland, April 2004

1171 V. Anton Muscatelli, Patrizio Tirelli and Carmine Trecroci, Can Fiscal Policy Help Macroeconomic Stabilisation? Evidence from a New Keynesian Model with Liquidity Constraints, April 2004

1172 Bernd Huber and Marco Runkel, Tax Competition, Excludable Public Goods and User Charges, April 2004

1173 John McMillan and Pablo Zoido, How to Subvert Democracy: Montesinos in Peru, April 2004

1174 Theo Eicher and Jong Woo Kang, Trade, Foreign Direct Investment or Acquisition: Optimal Entry Modes for Multinationals, April 2004 